Oleg D. RUSTEMOV,

Candidate of Philology (PhD), Ardahan University, Turkey; Ardahan Üniversitesi, İnsani Bilimler ve Edebiyat

Fakültesi; Yenisey Kampüsü, Çamlıçatak Mevkii, Ardahan, 75000, Türkiye; tel.: +9 (0553) 1821607;

e-mail: biblos@ukr.net; olegrustemov@ardahan.edu.tr; ORCID ID: 0000-0001-6444-2885

\title{
TYPES AND FUNCTIONS OF EZAFE CONSTRUCTIONS IN THE TEXTS OF THE CRIMEAN KHANATE KADIASKER'S BOOKS OF THE 17TH-18TH CENTURIES
}

Summary. The article deals in detail with the question of syntactic and stylistic functions of ezafe constructions that are present in the kadiasker collections of the Crimean Khanate of the 17th-18th cc. Ezafes are a distinctive feature of the syntax of Turkic languages. However, in the Crimean kadiasker notebooks not only ezafes of Turkic origin are used, but also Arab-Persian ones. Originally Turkic ezafes are presented both in classical form and in historical development, with reference to texts of legal substratum, characterized by their narrative character. Arab-Persian ezafes in a greater degree perform stylistic functions, and sometimes look like stenographic techniques. Often they also carry a terminological burden. All these features of the ezafe of kadasker's books evidence of a developed and well-established language, in particular, the style of legal lining.

Key words: ezafe, Crimean books, legal subtyle, syntax of Turkic language, stylistics.

Статтю отримано 21.03.2017 $p$.

http://dx.doi.org/10.18524/2307-4558.2017.27.107896

УДК 811.161.1'373.74'282.4:304.3(477.74)

\section{АРЕФБЕВА Наталья Георгиевна,}

кандидат филологических наук, доцент кафедры языковой и общегуманитарной подготовки иностранцев Института международного образования Одесского национального университета имени И. И. Мечникова; пер. Маяковского, 7, г. Одесса, 65082, Украина; тел.: 095-866-32-87; e-mail: n.arefieva@onu.edu.ua; ORCID ID: $0000-0002-4974-9157$.

\section{ФРАЗЕОЛОГИЧЕСКАЯ КАРТИНА МИРА СКВОЗЬ ПРИЗМУ ЛИНГВОКУЛЬТУРНЫХ КОДОВ (на материале русских говоров Одесщины)}

Аннотация. Цель статьи - попытка реконструировать фразеологическую картину мира носителей русских говоров Одесского региона. Предмет исследования составляют лингвокультурные коды, планом выражения которых являются фразеологизмы, зафиксированные в двухтомном Словаре русских говоров Одесщины. Методологической основой исследования стали современные разработки и основные положения лингвокультурологии, когнитивной лингвистики, диалектологии и лингвосемиотики. На основе обширного пласта фразеологизмов русских говоров Одесщины выделен 21 лингвокультурный код. Некоторые из них рассмотрены на фоне лингвокультурологической парадигмы. Результатом исследования стали выводы, согласно которым фразеологическая картина мира может быть реконструирована с помощью лингвокультурных кодов. Фразеологическая картина мира носителей русских переселенческих говоров Одесской области отличается широтой и многообразием, воссоздаёт быт, культурные традиции, социокультурные и природные условия, в которых проживают диалектоносители, а также отражает стереотипы и эталоны, на которые ориентируются русскоязычные жители Одесского региона. Базовым лингвокультурным кодом фразеологической картины мира является хозяйственный код, вокруг которого группируется значительная часть других лингвокультурных кодов.

Ключевые слова: русские говоры Одесщины, фразеологизм, фразеологическая картина мира, лингвокультурный код.

Постановка проблемы. Фразеология русских говоров Одесщины сегодня - уникальный, наименее изученный языковой пласт, в котором преломляются быт, история, традиции и мировоззрение народа-диалектоносителя. В то же время, лингвокультурологические исследования диалектных фразеологизмов как никогда актуальны, поскольку “лексика общерусского и диалектного дискурсов в целом отражает дискретное единое и непрерывное ментальное пространство всех носителей русского языка. При моделировании общерусской (общенациональной) ЯКМ диалектные факты могут восполнить отдельные её звенья, отсутствующие в сознании носителей современного литературного языка» $[4$, с. 19$]$. Об актуальности поставленной научной проблемы говорит и автор учебного пособия «Лексика русских переселенческих говоров Одесской области, функционирующих в иноязычном окружении» Л. Ф. Баранник. “Богатая и интереснейшая фразеология русских говоров Одесщины ждёт своих исследователей»), - отмечает учёный [1, с. 19].

Связь с предыдущими исследованиями. Нужно отметить, что в русле лингвокультурологических и этнолингвистических студий фразеологию исследовали Н. И. Толстой, В. М. Мокиенко, Е. А. Селиванова, Д. О. Добровольский, В. Н. Телия, В. Д. и Д. В. Ужченко, К. Ничева, И. А. Голубовская, 
Е. А. Левченко, И. В. Зыкова, В. В. ЖЯайворонок, М. Л. Ковшова, В. И. Кононенко, Л. П. Дядячко, Д. П. Амичба, А. А. Майборода, Л. В. Мельник, Н. Г. Арефьева и др. Лингвокультурологическим исследованиям диалектной фразеологии посвящены работы Е. В. Брысиной, С. М. Беляковой, В. Д. Ужченко, В. Ю. Краевой и других. Лингвокультурная специфика фразеологизмов в социокультурном пространстве города рассмотрена в докторской диссертации и ряде других работ Е. Н. Степанова [9-13]. В то же время, как отмечалась выше, вопрос о комплексном изучении фразеологии русских говоров Одесщины, в том числе с позиций лингвокультурологии, остаётся открытым.

Научная новизна данного исследования состоит в том, что в ней фразеологизмы рассматриваются сквозь призму лингвокультурных кодов, под которыми мы, вслед за В. А. Масловой, понимаем (глубинное культурное пространство, в котором разные языковые сущности получают различные культурные смыслы, заполняя собой и формируя тем самым код) [5, с. 81]. Разделяя мнение В. В. Красных о том, что “набор кодов культуры для человечества универсален, однако их проявления, удельный вес каждого из них в определённой культуре, а также метафоры, в которых они реализуются, всегда национально детерминированы и обусловлены конкретной культурой» [3, с. 232], заметим, что исследование лингвокультурных кодов в перспективе не только помогает раскрыть языковую и концептуальную картины мира (ЯКМ и ККМ) диалектоносителей, но и решает общеязыковую проблему “взаимодействия, взаимовлияния территориально смежных языков и говоров", проблему (межъязыковых и междиалектных контактов", чрезвычайно актуальную и в наши дни [2, с. 7], а также открывает широкие перспективы в решении проблемы интеракции языка и традиционной духовной культуры, поскольку “код вырабатывается и функционирует в культуре» [6, с. 137]. Отметим также, что понятие лингвокультурного кода "находится на начальной стадии разработки и лишь начинает свой путь в качестве категории лингвосемиотики и лингвокультурологиим [7, с. 3].

Постановка иселедовательских задач. Цель данной статьи - попытка реконструкции фразеологической картины мира русских говоров Одесщины, раскрыть которую помогают лингвокультурные коды. Предмет исследования составляют лингвокультурные коды, планом выражения которых являются фразеологические единицы русских говоров Одесщины, что позволяет значительно расширить инструментарий терминологического аппарата лингвокультурологии и под другим углом зрения подойти к разрешению проблемы моделирования фразеологической картины мира диалектоносителя.

Под фразеологической картиной мира (далее ФКМ) мы понимаем миропонимание и мироощущение народа-носителя языка (в нашем случае - диалектоносителя), имплицитно и эксплицитно представленное во фразеологических единицах.

Задачи исследования состоят в том, чтобы выявить и описать ФКМ носителей русских говоров Одесщины, опираясь на лингвокультурные коды как сгусток культурных смыслов, выраженных языковыми средствами. Методами исследования являются лингвокультурологический анализ, который включает концептуальный анализ, анализ словарных дефиниций, описательный и сопоставительный методы, метод ретроспекции и интроспекции, квантитативный метод.

Ивложение основного материала. Опираясь на богатейший материал двухтомного Словаря русских говоров Одесщины (далее СРГО) и используя метод сплошной выборки (в том числе на материале записанных текстов, включённых в Словарь), нами было зафиксировано около трёхсот устойчивых сочетаний-фразеологических единиц. Здесь под фразеологической единицей (далее ФЕ) мы понимаем не только собственно идиоматические сочетания слов, но и пословицы, поговорки (Гуртом да миром сподручней, Поговорочка его лежит у сердца моего), составные наименования, широко распространённые в данном регионе, как-то: бежевый платок - 'платок любого цвета из тонкой шерсти с кистями'; прибыльная вода - 'вода, прибывшая в реке в половодье' [8, т. 1, с. 35; т. 2, с. 107], номенклатурно-терминологические словосочетания (белый кудрик - 'сорт винограда'; железная лавка - 'магазин хозяйственных товаров' [8, т. 1, с. 36, 193]), тавтологические сочетания слов (край на край - 'в конце концов, наконец'; дашь-на-дашь - 1) 'поровну'; 2) 'взаймы' [8, т. 1, с. 266,157$])$, а также предложно-именные сочетания, соотносящиеся с наречиями, предлогами или союзами (с пупенка - нареч., әкспресс. 'с младенчества'; до путя - 'хорошо' [8, т. 2, с. 186; т. 1, c. 170]).

На основе обширного пласта фразеологизмов русских говоров Одесщины нами выделен 21 лингвокультурный код: хозяйственный (стоять на горне - 'работать кузнецом', обселить основу - 'продеть продольные нити, идущие вдоль домотканого полотна' - всего 44 ФЕ); социальный (убиться в пьянку - 'спиться', нема моду - 'не заведено, не принято' - всего 32 ФЕ); флористический (растительный) (цвет кидать - 'цвести', давать род - 'плодоносить' - всего 29 ФЕ); соматический (на чьей-либо голове - 'на памяти', в сердцах - 'в ссоре' - всего 25 ФЕ); анималистический (зооморфный) (показывать горобцам дули - 'бездельничать', взять за зябры - 'оказать давление' всего $24 \Phi \mathrm{E})$; свадебный (продавать невесту - 'просить выкуп за невесту по старинному свадебному обряду', бабичья свадьба - 'угощение для женщин после венчания' - всего 20 ФЕ); гендерный (хрустальная жена - 'жена (не первая) человека, женившегося в преклонном возрасте', старый парень - 'старый холостяк' - всего 20 ФЕ); природный (синий камень - 'медный купорос', тучевой дождь - 'ливень' - всего 20 ФЕ); бытовой (уборная хата - 'гостиная', передний кут - 'красный 
(передний) угол в доме, в котором находится икона, куда сажают почётных гостей' — всего 19 ФЕ); предметный (вещный) (стоялая пряха - 'стоячая прялка, высокая', адегиное намысто - 'бусы, плотно прилегающие к шее' - всего 18 ФЕ); гастрономический (пищевой) (пуканки пукать 'готовить жареные кукурузные зёрна (поп-корн), употребляемые в пищу', борщевой квас - 'приправа для борща' - всего 13 ФЕ); временной (край на край - 'в конце концов, наконец', да и годя - 'да и всё, да и только' - всего 13 ФЕ); пространственный (нема куды - 'некуда', полнеполным - 'полным-полно' - всего 11 ФЕ); духовный (бога не острашаться - 'бога не бояться', у гурте - (вместе, сообща) - всего 10 ФЕ); космогонический (век завязывать - 'укорачивать жизнь', свет потерять - 'потерять зрение' - всего 8 ФЕ); интеллектуальный (пораскинуть розумом - 'пораскинуть мозгами', пропить розум - 'спиться' - всего 7 ФЕ); семейный (брат под братом - 'младший брат', малый родственник (малая родственница) - 'дальний родственник' - всего 7 ФЕ); транспортный (драбинный воз - 'повозка с решётчатыми боковинами, арба', файтон без коней - 'автомобиль' - всего 4 ФЕ); антропонимический (Ванька-встанька - 'божьЯ коровка', Ваня-рутютю - 'божья коровка' - всего $2 \Phi \mathrm{E}$ ); ландшафтный (вгору крычать - 'петь высоким голосом' - всего 1 ФЕ); эмоциональный (в горячках — 'сгоряча' — всего $1 \Phi \mathrm{E})$.

Рассмотрим функционирование некоторых кодов в диалектной речи. Хозяйственный код занимает ведущее место в ФКМ носителя русских говоров Одесского региона, представлен наибольшим количеством $\Phi \mathrm{E}$, что вполне естественно, поскольку хозяйственная деятельность занимает исключительно важное место в жизни жителя села. Ср.: гарод делать - 'обрабатывать огород': У нас римесил нет, мы фбсе гароды делаим (Ст. Некр.) [8, т. 1, с. 140]. Или: Уладить (улаживать) вемлю 'распахать, разрыхлить, обработать землю': Пришло время уладить вемлю (Вилк.). Вясной вемлю улажывали (Вилк.) [8, т. 2, с. 243]. С хозяйственным кодом тесно связаны коды бытовой и предметный (бунбаковые рушники - устар. 'домотканые полотенца, вышитые разноцветными нитками': Вот бунбакавыи рушники - мы их сали пряли и вышивали (Усп.) [8, т. 1, с. 56], а также природный, поскольку природные условия чрезвычайно важны для ведения хозяйства и являются предметом вековых наблюдений народа-носителя: спокойный дождь — 'тихий дождь': Спакойный дождь - тихий, без ветра, салый хароший для уражаю (Введ.) [8, т. 2, с. 184].

На втором месте - код социальный, что также объяснимо, т. к. социализация в обществе, стереотипы поведения, оценка общества всегда были чрезвычайно важны для славянина: прикласть ввание - 'прозвать': А ён абидился, ита я йилу приклав ввания Видлидёбб (Рус. Ив.). Как прикладут ввания - ни аутанит (Алекс.) [8, т. 2, с. 109].

Флористический код занимает третье место в иерархии кодов культуры носителей говоров и представлен широким разнообразием названий растений, овощных культур, плодовых деревьев. Флористический код также пересекается с кодом хозяйственным: синие помидоры - 'баклажаны': Синие памидоры и угуриики в кадушки солим (Дем.). Синие памидоры садють, красные памидоры, картоху, изыбульюу (Возн.) [8, т. 2, с. 168]. Обращает на себя внимание высокая продуктивность лексем полевой и степовой в составе ФЕ флористического кода: степовая василька - 'сорняк'; степовой ковёрчик - 'сорняк, который расстилается по земле'; степовые ротики - 'степной сорняк'; полевая роза - 'мальва'; полевой цветок - 'цветок красного цвета, по форме напоминающий кисточку' [8, т. 2, с. 192, 65]. Здесь флористический код тесно переплетается с кодом ландшафтным, отражая природные особенности Одесского региона. Количественное же доминирование фолористического кода над анималистическим, также пронизанным широким спектром сравнений и стереотипов, связанных во фрразеотворчестве русского диалектоносителя с животным миром, свидетельствует, на наш взгляд, о большей значимости растениеводства в сравнении со скотоводством в хозяйственной деятельности русских. Отсюда многообразие наименований цветов, растений, сортов овощей и фрруктов, бережное отношение к которым проявляется и в обилии уменьшительных форм, и в образности сравнений. Ср.: беленький подсолнушек - 'ромашка': $A$ вон тал белинький патсолнушык растёть (Ст. Некр.) [8, т. 1, с. 35]; ночная красота - 'маттиола': На базари мне залеста начной красаты зорик дали (Ст. Некр.) [8, т. 1, с. 331]; красная серебрина - 'шиповник': Красную сирибрину ат кашлю харашо (Петр.) [8, т. 1, с. 267].

Хозяйственный и анималистический коды могут пересекаться: тугая корова - 'корова, которую трудно раздоить': Харошая каровка, малако у ней укуснае, но дюжа тугая (Возн.); дивьи патки - 'дикие гуси': Диви патки в жамышах: лавить можна и кушать (Сув.) [8, т. 2, с. 230; т. 1, с. 167]. Анималистический код представлен $\Phi Е$, имплицитно и эксплицитно репрезентирующих и домашних животных (стоялый конь - 'откормленный конь, не работавший'; мотнуть хвостом 'быстро уйти'; воловий язык - 'растение, чернокорень аптечный'; водить цыплят - 'высиживать цыплят (о курице, индюшке)'), и птиц (показывать горобцам дули - 'бездельничать'), и рыб (богова рыбка - 'тысячелистник'), и пчёл (работня пчела - 'медоносная пчела'), и даже ядовитых змей (гадючье молоко - 'растение молочай'; растение гадючий виноград), обитающих в Одесской области. Лингвокультурными концептами анималистического кода можно считать концепты (корова», ((вол), (пчела), представленные наибольшим количеством ФЕ.

Выводы. Как видим, ФКМ носителей русских говоров Одесщины, частично реконструированная нами сквозь призму лингвокультурных кодов, широка и многообразна. Она воссоздаёт быт, культур- 
ные традиции, социокультурные и природные условия, в которых проживают диалектоносители, а также отражает стереотипы и эталоны, на которые ориентируются русскоязычные жители Одесского региона: Гуртом да миром сподручней. Базовым лингвокультурным кодом ФКМ является код ховяйственный, вокруг которого группируется значительная часть других лингвокультурных кодов.

Перспективы дальнейших исследований видятся нам в расширении базы исследования: использование не только данных словаря, но и материалов новых специализированных полевых исследований на основе записи диалектных текстов, а также более глубокое комплексное исследование каждого лингвокультурного кода. Кроме того, предполагается установить и описать межъязыковые и межкультурные связи, оказавшие влияние на формирование ФКМ носителей русских говоров Одесщины.

\section{Литература}

1. Баранник Л. Ф. Лексика русских переселенческих говоров Одесской области, функционирующих в разноязычном окружении : учеб. пособие / Л. Ф. Баранник. - Одесса : Одесский национальный университет имени И. И. Мечникова, 2015. - 178 с.

2. Баранник Л. $\Phi$. Региональная языковая картина мира носителей русских островных говоров Одесской области / Л. Ф. Баранник // Мова : науково-теоретичний часопис з мовознавства. - Одеса : Астропринт, 2014. - № $22 .-$ C. $7-11$.

3. Красных В. В. Этнопсихолингвистика и лингвокультурология : Лекционный курс / В. В. Красных. - М. : Гнозис, 2002. - $284 \mathrm{c}$

4. Луквянова Н. А. Когнитивные источники образных слов русского языка / Н. А. Лукьянова // Русистика : сб. науч. трудов. - Киев : ИЦ КНУ, 2008. - Вып. 8. - С. 18-27.

5. Маслова В. А. Особенности описания языка сквозь призму лингвокультурных кодов / В. А. Маслова // Матеріали V Всеукраїнської науково-практичної конференції (Лінгвістичні та лінгвокультурологічні аспекти навчання іноземних студентів у вищих навчальних закладах України (31 березня -1 квітня 2016 р.). - Дніпропетровськ, 2016. - C. 81-87.

6. Маслова В. А. Русский язык как совокупность кодов : растительного, архитектурного, духовного / В. А. Маслова // Учёные записки Таврического нац. ун-та им. В. И. Вернадского. Сер. “Филология. Социальные коммуникациил. - Симферополь, 2011. - Т. 24 (63). - № 1. - Ч. 1. - С. 137-140.

7. Попова А. Н. Взаимодействие лингвокультурных кодов в речеязыковом пространстве (на материале английского языка) : автореф. ... канд. филол. н. : спец. 10.02.04 - „Германские языки» / А. Н. Попова. - Самара, 2014. - 22 с.

8. Словарь русских говоров Одесщины / [ред. коллегия : проф. Ю. А. Карпенко (отв. ред.), проф. С. Уэмура, проф. Д. С. Ищенко, доц. Л. Ф. Баранник] : в 2 т. - Одесса : АстроПринт, 2000-2001.

9. Степанов $E$. H. Русская городская речь в полилингвокультурном пространстве Одессы : автореф. дис. ... докт. филол. н. : спец. 10.02.02 - «Русский язык» / Е. Н. Степанов. - Киев, 2013. - 35 с.

10. Степанов E. Н. Фразеология города как лингвокультурное пространство / Е. Н. Степанов // Науковий вісник Ізмаїльського державного гуманітарного університету. - Ізмаїл, 2008. - Вип. 25. - С. 130-135.

11. Степанов E. H. Городская фразеология Одессы и Санкт-Петербурга как отражение их лингвокультурологических пространств / Е. Н. Степанов // Слово есть Дело : Юбилейный сборник научных трудов в честь проф. И. П. Лысаковой. - СПб. : Сударыня, 2010. - Т. 1. - С. 112-122.

12. Степанов E. H. Городская фразеология Санкт-Петербурга как отражение социально-исторических событий петровской эпохи / Е. Н. Степанов // Полтавская битва и Прутский поход Петра I : история, политика, философия I половины XVIII века : Научно-публицистический сборник. - Кишинёв : Славянский университет, 2010. - С. $105-113$.

13. Степанов E. H. Фразеология русского воднотранспортного дискурса в текстах разных стилей / Е. В. Галяс, Е. Н. Степанов // Поддержка русского языка как основы развития интеграционных процессов в СНГ : Материалы регионального форума молодых преподавателей русского языка, аспирантов и студентов-русистов. Минск, 21-24 ноября 2011 г. - М.-Минск-Тула, 2011. - С. 37-39.

\section{References}

1. Barannik, L. F. (2015), Vocabulary of Russian migrant dialects of Odessa region, functioning in the multilingual environment [Leksika russkikh pereselencheskikh govorov Odesskoj oblasti, funkcionirujuschikh v raznojazychnom okruzhenii : ucheb. posobie], Odessa I. I. Mechnikov National Univ., Odessa, 178 p.

2. Barannik, L. F. (2014), "Regional linguistic image of the world of carries of Russian insular dialects of Odessa region», Mova [“Regionalnaja jazykovaja kartina mira nositelej russkikh ostrovnykh govorov Odesskoj oblasti], Odessa I. I. Mechnikov National Univ., Astroprynt, Odessa, vol. 22, pp. 7-11.

3. Krasnykh, V. V. (2002), Ethnopsycholinguistics and linguoculturology [Etnopsikholingvistika i lingvokulturologija : Lekcionnyj kurs], Gnosis, Moscow, 284 p.

4. Lookjanova, N. A. (2008), "Cognitive sources of imaginative Russian words», Russian studies ["Kognitivnye istochniki obraznykh slov russkogo jazyka», Rusistika], Publishing Center of Kiev T. Shevchenko National Univ., Kiev, vol. 8, pp. 18-27.

5. Maslova, V. A. (2016), "Peculiarities of language description in the light of linguocultural codes», Materials of the Vth All-Ukrainian Scientific and Practical Conference «Linguistic and cultural aspects of teaching foreign students in higher educational institutions of Ukraine (March 31 - April 1, 2016) ["Osobennosti opisanija jazyka skvoz prizmu lingvokulturnykh kodov", Materialy V Vseukrai'ns'koi' naukovo-praktychnoi' konferencii' "Lingvistychni ta lingvokul'turologichni aspekty navchannja inozemnykh studentiv u vyshhykh navchal'nykh zakladakh Ukrai'ny" (31 bereznja - 1 kvitnja 2016 r.)], Dnipropetrovs'k, pp. 81-87.

6. Maslova, V. A. (2016), "The Russian language as a system of codes : vegetal, architectural, spiritual and others), Scientific Notes of Taurida National V. I. Vernadsky University. Ser. Philology. Social Communications ["Russkij ja- 
zyk kak sovokupnost kodov : rastitelnogo, arkhitekturnogo, dukhovnogo", Uchenye zapiski Tavricheskogo nac. un-ta im. V. Y. Vernadskogo. Ser. Fiologija. Social'nye kommunikacii], Simferopol', vol. 24 (63), No. 1, part 1, pp. 137-140.

7. Popova, A. N. (2014), Linguocultural codes' interaction in the speaking-lingual space (based on the English language): Author's thesis [Vzaimodeystvie lingvokulturnykh kodov v rechejazykovom prostranstve (na materiale anglijskogo jazyka) : avtoref. dis.... kand. filol. nauk], Samara, $22 \mathrm{p}$.

8. Russian dialects of Odessa region Dictionary : in 2 vol. (2000-2001), [Slovar' russkikh govorov Odesschiny : v $2 t$.], Astroprint, Odessa.

9. Stepanov, Ie. N. (2013), Russian urban speech in the multilingvocultural space of Odessa: Author's thesis $[$ Russkaja gorodskaja rech v polilingvokulturnom prostranstve Odessy : avtoref. dis.... dokt. filol. nauk], Oleksandr Potebnya Institute of Linguistics of the Ukrainian NAS, Kyiv, $35 \mathrm{p}$.

10. Stepanov, Ie. N. (2008), "Phraseology of the city as a lingual and cultural space", Scientific Bulletin of Izmail State University of Humanities ["Frazeologija goroda kak lingvokul'turnoe prostranstvo ", Naukovyj visnyk İzmaïl's'kogo derzhavnogo gumanitarnogo uníversytetu], IDGU Press, Izmail, vol. 25, pp. 130-135.

11. Stepanov, Ie. N. (2010), "The urban phraseology of Odessa and St. Petersburg as a reflection of their linguistic and cultural spaces", The Word is the Matter : Jubilee collection of scientific works in honor of prof. I. P. Lysakova ["Gorodskaja frazeologija Odessy i Sankt-Peterburga kak otrazhenie ikh lingvokul'turologicheskikh prostranstv", Slovo yest' Delo : Yubileynyj sbornik nauchnykh trudov v chest' prof. I. P. Lysakovoj], Sudarynia, St. Petersburg, vol. 1. - pp. 112-122.

12. Stepanov, Ie. N. (2010), "Urban phraseology of St. Petersburg as a reflection of the socio-historical events of the Petrine eran, The Battle of Poltava and the Prut march of Peter the Great : history, politics, philosophy of the first half of the 18th century : Scientific and journalistic collection ["Gorodskaja frazeologija Sankt-Peterburga kak otrazhenie social'no-istoricheskikh sobytij petrovskoj epokhi», Poltavskaja bitva i Prutskiy pokhod Petra Í : istorija, politika, filosofija Í-oj poloviny XVIII veka : Nauchno-publicisticheskij sbornik], Slavic University of Moldova, Chisinau, pp. 105-113.

13. Stepanov, Ie. N., Galias, Ie. V. (2011), "Phraseology of Russian water transport discourse in texts of different styles", Support for the Russian language as the basis for the development of integration processes in the CIS :Materials of the regional forum of young teachers of Russian language, postgraduate students and students of Russian philology, Minsk, November 21-24, 2011 ["Frazeologija russkogo vodnotransportnogo diskursa v tekstakh raznykh stilej», Podderzhka russkogo jazyka kak osnovy razvitija integracionnykh processov $v$ SNG : Materialy regional'nogo foruma molodykh prepodavatelej russkogo jazyka, aspirantov $i$ studentov-rusistov, Minsk, 21-24 nojabrja 2011 g.], Moscow, Minsk, Tula, pp. $37-39$.

\section{АРЕФЬСВА Наталія Георгіївна,}

кандидат філологічних наук, доцент кафедри мовної та загальногуманітарної підготовки іноземців Інституту міжнародної освіти Одеського національного університету імені I. I. Мечникова; пров. Маяковського, 7, м. Одеса 65082, Україна; тел.: 095-8663287; e-mail: n.arefieva@onu.edu.ua; ORCID ID: 0000-0002-4974-9157

\section{ФРАВЕОЛОГІЧНА КАРТИНА СВІТУ КРІЗЬ ПРИЗМУ ЛІНГВОКУЛЬТУРНИХ КОДІВ (на матеріалі російських говірок Одещини)}

Анотація. Метою статті є спроба реконструювати фразеологічну картину світу носіїв російських говірок Одеського регіону. Предмет дослідження становили лінгвокультурні коди, планом вираження яких стали фразеологізми, що були зафіксовані у двохтомному Словнику російських говірок Одещини. Методологічною основою дослідження стали сучасні розробки й основні положення лінгвокультурології, когнітивної лінгвістики, діалектології та лінгвосеміотики. На підгрунті значного шару фразеологізмів російських говірок Одещини виокремлено 21 лінгвокультурний код. Деякі з них розглянуто на тлі лінгвокультурологічної парадигми. Результатом дослідження є висновки, згідно з якими фразеологічна картина світу може бути реконструйована за допомогою лінгвокультурних кодів. Фразеологічна картина світу російських переселенців Одеської області відрізняється широтою та різноманіттям, відтворює побут, культурні традиції, соціокультурні та природні умови, в яких мешкають носії діалектів, а також віддзеркалює стереотипи й еталони, на які орієнтуються російськомовні мешканці Одеського регіону. Базовим лінгвокультурним кодом $\mathrm{G}$ господарський код, навколо якого згуртована значна частина інших лінгвокультурних кодів.

Ключові слова: російські говірки Одещини, фразеологізм, фразеологічна картина світу, лінгвокультурний код.

\section{Natalia G. AREFIEVA,}

Candidate of Philological Sciences (PhD), Associate Professor of the Chair of Linguistic and General Humanitarian

Training for Foreigners, Institute of International Education, Odessa I. I. Mechnikov National University; 7, Mayakovsky lane, Odessa, 65082, Ukraine; tel.: +38 095-8663287; e-mail: n.arefieva@onu.edu.ua; ORCID ID: 0000-0002-4974-9157

\section{PHRASEOLOGICAL PICTURE OF THE WORLD IN THE LIGHT OF LINGUOCULTURAL CODES (based on the Russian dialects of Odessa region)}

Summary. The purpose of the article is the first attempt to reconstruct phraseological picture of the world of the Russian dialects' speakers of Odessa region. The subject of this study was linguocultural codes, the plan of expression which was the phraseological units, fixed in the two-volume Russian dialects of Odessa region's Dictionary. Methodology of this investigation includes the main theses and recent scientific advances in the sphere of linguoculturology, cognitive linguistics, dialectology and linguosemiotics. On the basis of the wide phraseological material of the Russian dialects of Odessa region the 21 linguocultural codes are allocated. Some of them are considered on the background of the linguocultural paradigm. The author comes to conclusion that the phraseological picture of the world can be reconstructed with the 
help of linguocultural codes. The phraseological picture of the world of Russian settlers of Odessa region is distinguished by width and diversity, reflects mode of life, cultural traditions, sociocultural and natural conditions in which the dialects' speakers live, as well as stereotypes and standards, which influence on Russian-speaking residents of Odessa region. The main linguocultural code is the economic code, around which the big part of other codes is grouped. code.

Key words: Russian dialects of Odessa region, phraseological unit, phraseological picture of the world, linguocultural

Статтю отримано 22.03.2017 p.

http://dx.doi.org/10.18524/23074558.2017.27.107884

УдК 811.163.2'282.2'373.46:58(477:1-924.56)

ГОНЧАР Наталя Миколаївна,

кандидат філологічних наук, доцент кафедри загального мовознавства, слов'янських мов та світової літератури Ізмаїльського державного гуманітарного університету; вул. Рєпіна,12, м. Ізмаїл, 68600, Україна; тел.: +38 097 5117632; e-mail: nat.gonchar1974@yandex.ua; ORCID ID: 0000-0003-1295-2992

\section{БОТАНІЧНА ЛЕКСИКА В БОЛГАРСЬКИХ ГОВІРКАХ УКРАЇНСЬКОГО ПОДУНАВ’Я}

Анотація. Мета статті - описати ботанічну лексику в болгарських діалектах, вивчити й систематизувати терміносистему, яка використовується в болгарському континуумі, дослідити основні тенденції її розвитку в діалектах Подунав'я. Предметом розгляду є опис і функціонування фітонімів лексико-семантичної групи сільськогосподарських культур. У результаті проведеного дослідження представлено репертуар фолорономенів на позначення злакових, технічних та городніх культур у болгарських діалектах межиріччя Дністра й Дунаю. Подано загальну характеристику та класифікацію просторової диференціації ботанічної лексики. Виявлено, що болгарські назви сільськогосподарських рослин у сучасних переселенських говірках болгар Одещини відображають характерні особливості місцевих діалектів, носіями яких були болгарські мігранти XVIII-XIX ст. Усі досліджені говіркові назви наслідують основні принципи номінації, характерні для фолоронайменувань болгарської мови. Висновки. В болгарських діалектах склалася доволі повна, ємна й цілісна система фітонімів. Дослідження лексико-тематичного шару сільськогосподарських фітонімів дає достатнє уявлення про характер діалектної лексики, збережені діалектні архаїчні ознаки. Більшість досліджених фітономенів у болгарських говірках України сформувалася на загальнослов'янському грунті, але можуть виявляти семантичну специфіку місцевих діалектів. Болгарські говірки півдня України становлять собою значний науковий інтерес і потребують подальших досліджень і картографування.

Ключові слова: ботанічна лексика, фітоніми, номени, варіанти, болгарські діалекти, українське Подунав'я.

Постановка проблеми. На території України існує кілька мікроареалів з компактним проживанням представників різних національностей, де в межах одного населеного пункту можуть співіснувати кілька діалектів, споріднених і неспоріднених різноструктурних мов. На території одного з таких ареалів на півдні Одеської області компактно мешкає численна болгарська діаспора, що понад 200 років функціонує дистантно від мови метрополії.

Особливість цього діалектного континууму полягає в тому, що він представляє новостворений масив, сформований внаслідок заселення території вихідцями з різних регіонів Болгарії і становить зону контактування різних типів болгарських діалектів з говірками української, російської, гагаузької та молдавської мов.

Одним з актуальних завдань діалектного дослідження таких ареалів 6 різноаспектне вивчення лексики в її сучасному стані та історичному розвитку. Необхідність системного вивчення ботанічної лексики в болгарських діалектах півдня України й типів ареальної поведінки номінативних одиниць зумовила актуальність роботи. Для всебічного вивчення ботанічної лексики необхідна повна її систематизація та картограффвання.

Зв'язок проблеми з попередніми дослідженнями. В опублікованих до сьогодні працях досліджено найменування лексики в окремих болгарських селах Бессарабії $[1 ; 2 ; 3 ; 6]$, складено словники говірок болгарських сіл Одещини $[2 ; 5 ; 6 ; 9]$. Досі немає системних описів лексико-семантичних шарів лексики болгарських переселенських говірок Одещини, відсутні роботи, що систематизують фітоніми і визначають динаміку змін у назвах рослин.

Постановка завдання. Наше дослідження виконано відповідно до тематики, передбаченої планом науково-дослідної роботи кафедри загального мовознавства, слов'янських мов та світової літератури Ізмаїльського державного гуманітарного університету за напрямом наукового пошуку в рамках проекту МОН України “Опис і картограффування межиріччя Дністра і Дунаю - нової європейської моделі безконффліктної взаємодії різносистемних мов і діалектів».

Мета пропонованої статті - описати лексико-семантичний шар сільськогосподарської ботанічної лексики в південноболгарських бесарабських діалектах, вивчити й систематизувати терміносистему, 